\title{
Social and Emotional Learning Competencies and Academic Achievement: A Study on Students in Senior High Schools in Ghana
}

\author{
Article by Juliet Yayra Tengey \\ Texila American University, Ghana Military Academy \\ Email: julietedwinatengey@gmail.com
}

\begin{abstract}
The concept of Social and emotional learning (SEL) is instituted on the positive youth development which promotes the needs of youth to be addressed by building backgrounds that encourage outcomes conforming to school achievement, correspondingly sympathetic relationships with adults and peers, problem solving, and civic engagement amongst others. Much focus has been on students' achievement, thus passing examination and neglecting the other very important aspect of students' life which are acquiring skills in problem sovling, building relationships just to mention a few. The study thus sought to examine students' own social and emotional learning competencies (self awareness, social awareness, selfmanagement and responsible decision making) in the Greater Accra and Ashanti Regions of Ghana. One hundred and thirty students constituted the sample. Eighty from Kumasi metro schools and fifty from Accra Metro schools in the Ashanti and Greater Accra regions respectively. The SELC questionnaire was used to collect data while the convenient sampling technique was used in selecting participants. Results indicated amongs others that female students scored higher on the social emotional competencies than their male counterparts.
\end{abstract}

Keywords: Social and Emotional Learning Competencies, Social and Emotional Learning, self awareness, social awareness, self-management, responsible decision making, Problem solving, Ghana.

\section{Introduction}

The rising wave of examination malpractices in the country sent a lot of thoughts that motivated the conduction of this research. In reading around the subject area, and reviewing related articles, there was a write up on Ghanaweb, myjoyonline.com by Stan Dugah about a student from keta senior high that hit the nail right on the head. The student stated, "It was sometime in May, 2009. I was living with friends in a rented house in Keta, and we were preparing for the 2009 May/June WASSCE. We were four; two of us in Ketasco and the other two in Ketabusco. On the eve of the Mathematics paper, sometime in the evening, a girl from Zion College, Anloga, being a girlfriend to one of the Busco boys, came visiting, and showed us some questions she got from God knows where. I recall her telling us that they were the Maths questions that will be appearing in the exam the very next day. We were very good students, hence, were not very much enthusiastic of getting hold of some easy "apor", (leaked examination questions) But we took a look at it anyway, and had our doubts confirmed. The questions appeared "too cheap" to be the ones that will appear in the exams; so said we among ourselves, and didn't even bother solving them. Come the next day, we went to write the Maths paper and those very questions appeared. That was the first time I had the experience of knowing that exam questions can truly get leaked. Later on I wondered how this could be, and surmised that it was all because we have a messed up education system that focuses more on exam passing than skill possession and imaginative/creative thinking, hence the unbounded desire on the part of most students (especially the super lazy ones, which is the 
South American Journal of Academic Research

Volume 3, Issue 1, 2016

majority) to pass their exams by hook or crook". He further on stated that upon hearing the news of examination malpractices that led to the cancellation of the Basic Education Certificate Examination (BECE) he asked, "Is it not because we have an education system that prefers rote learning to study in depth? Is it not because we have an education system that is tailored to exam passing more than the acquisition of life skills, critical thinking, and imaginative thought on the part of students?”...

This goes a long way in lending support to researchers who have posited that there is a significant gap between what students' learn in the classroom and that of what they acquire in their real or future world, and education being examination centerd rather than promoting students' overall success (Anamuah-Mensah \& Towse, 1995; Stevenson, 1995, Tengey \& Ganu; 2015). As one of the main national establishments responsible for conveying information and principles from one generation to the next, schools are to characteristically be involved in seeing to the social-emotional well-being of their students, in addition to their academic achievements.

Social-emotional learning has developed as an important, proper and formal method used in schools to provide guidance for students' behaviour. Social-emotional learning focuses on the skills and attitudes needed to function in relevant social environments. Social-emotional learning focuses mainly on the influence of problem solving (Elias, Zins, Weissberg et al., 1997; Huitt, 2004). On the other hand, academic achievement is the main focus of schools and stakeholders on preparation of students towards passing examinations. Academic achievement purposely focuses on classroom teachers primarily taking responsibility for student academic achievement (Darling-Hammond, 2000), and most schools efficiently and effectively establish themselves towards that task (Engelmann \& Carnine, 1991). Academic achievement as measured by standardized test with the main focus of the practice of classroom teachers and school administrators.

Nobel Laureate, James Heckman, specified that the greatestmost achievements on education investments are "from nurturing children'snon-cognitive skills, giving them social, emotional and behavioural benefits that lead to success later in life...” (Heckman\& Masterov, 2004).

\subsection{Purpose of the study}

Most educators and stakeholders concentrate mostly on the classroom knowledge and teaching to the detriment of teachings outside of the classroom which encompasses the overall education of students. More so, most curricula are examination-focussed, a reason of which educators take tremendously instructive classroom technique and approach to complete the curriculum just to fufil the expectations of students, parents and guardians, heads of institutions and other stakeholders who evaluate educational achievement mainly by results (Tengey \& Ganu; 2015). Concentration has been on students’ learning hard, “chew, pour, pass and forget” to the extent that, students pass examinations excellently yet lag behind when it comes to other spheres of their lives, for instance; public speaking, making presentations and taking up career related goals. (Tengey, 2015). Sufficient evidence have shown that students are not adequately prepared for the outside worldand of work by the educational system not only in the developing countries but also in the developed countries. Adequate effortsare being made to put things right, but with hazy levels of success (Noah \& Eckstein, 1988; Anamuah-Mensah \& Towse, 1995; Stevenson, 1995; Muskin, 1997; Tabron \& Yang, 1997, Tengey\& Ganu,2015: Tengey, 2015). The studysought to explore student's own (selfawareness, social awareness, self-management and responsible decision making)social and emotional learning competencies in senior high schools in the Accra and Kumasi Metropolis 
in the Greater Accra and Ashanti Regions in Ghana respectively. Relationship management was not included in the study purposely because it focuses on others. The study sought to investigate students own social and emotional competncies. The study sought to find out how well students knew and understood their own (intrapersonal) emotions.

\section{Theoretical framework}

\subsubsection{Emotional intelligence and student's emotional learning}

Robust school environments rely on the formation of a school culture that allows children to develop emotional intelligence competencies. Emotional intelligence is the skill to use emotions positively, successfully and competently. Emotional Intelligence competencies are developed from the ability to be aware of one's own emotions and inclinations of behaviour and to be able to handle negative or obstructive emotions resourcefully, to share in hopeful, positive and enthusiatic relationships and understandings with others in a way that increases learning and overall satisfaction. Researchers have postulated that total life satisfaction emanates from the advancement of Pro- social Behaviour, the antecedent of Empathy (Caprera et al., 2000; Malecki \& Elliott, 2002). Further studies reveals emotional intelligence is strongly connected to staying in school, barring risk behaviors, and nurturing health, happiness and life success. (Shriver \& Weissberg, 2005).

Lots of organizations have arisen to help schools and organizations establish emotional intelligence and social-emotional learning programs, including The Collaborative for Academic, Social and Emotional Learning (CASEL,2003). Emotional intelligence is emerging as a serious component for assisting and aiding in high achievement, retention, and positive behavior and also as promoting life success. Progressively, schools and educational establishments are engaging emotional intelligence in pursuing and advancing a systemic and total solution to develop outcomes both academic and social for example school attrition, studentsatisfaction, peer relations and well-being.

The fundermental stage in the emotional intelligence course is being conscious of our emotions and recognizing them. Research has it that affirming our emotions allows us to take a break and reflect on them before taking a move or an action, which permits a relationship between emotional and cognitive processes (Barbey, 2012). The emotional mind has to be cultivated to train and rehearse the skills of empathy and reflection, receive response from the surrounding environment, and measure the correctness of decisions made as a result of emotional contribution.

Research has it that identifying feelings starts to calm the mind, lessening our emotional reaction (Lieberman et al, 2007). Discussions on feelings and considering different opinions allows children to create communication between the emotional brain and the normal brain. When this is done, individuals can pause and reflect on the significance and importance of the emotions they are feeling and experiencing, focus and direct emotions and select the best way of accomplishment.

\subsubsection{Students' social and emotional learning}

There is a significant gap between what students' learn in the classroom and that of what they acquire in their real or future world (Anamuah-Mensah \& Towse, 1995; Stevenson, 1995, Tengey \& Ganu; 2015). Students' Social and Emotional Learning (SEL) otherwise known as "education of the whole child or total child education" can be defined as the way in which individuals become socially and emotionally intelligent. Futhermore, some generally define SEL as "the process through which children enhance their ability to integrate thinking, feeling, and behaving to achieve important life tasks" (Zins, Bloodworth, et al., 2007, p. 194). 
South American Journal of Academic Research

Volume 3, Issue 1, 2016

Programs put in place towards improving SEL are scheduled to help this process in systematic and all-inclusive manners within schools. The development and evaluation of SEL emanate from the early known writings about social and emotional skills and the increasing amount of interest and research on social or emotional intelligences over the past 150 years. Thisclassically began with Darwin's assessment of the significance of emotion in evolution, in The Expression of the Emotions in Man and Animals (Goleman, 1995; Mayer, 2001).

Thorndike's proposal of a "social intelligence" has also been cited to understand others and relate to them efficiently and effectivelyto overall intelligence (Elias, 2001). Sternberg's work (1985) on what he at that time referred to as "practical intelligence"established more empirical support for such a concept and ideology, and Gardner's research (1993) on multiple intelligences defined and supported two distinct and related components; intrapersonal (emotional) and interpersonal (social) intelligences. The Association on the School-based Promotion of Social Competence (1994) accentuated the importance of integrating cognition, affect, and behavior to address developmental and relative challenges and tasks. Prior to this idea, the study of intelligence, emotion, and social relations tended to be separate; with Sternberg and Gardner's work, it became clear that these phenomena were related to one another (Mayer, 2001), although others (e.g., Piaget and Dewey) had noted these interrelationships much earlier. By the late 1980s, much evidence supported the idea of incorporated social and emotional skills.

Mayer and Salovey also played aninfluential role in thoroughly defining and finding empirical backing for "emotional intelligence," as it is understood currently. In the first half of the 1990s, they produced a series of reviews and studies that offered support for emotional intelligence, provided a firm definition for the construct and a measure for assessing it, and demonstrated its validity and reliability as an intelligence (Mayer, 2001). Goleman propagated the concept and added some social components to the definition in his book, Emotional Intelligence (1995). Soonafterwards, Reuven Bar-On’s (Bar-On, Maree, \& Elias, 2007) extensive work in defining and assessing emotional intelligence came to fame. The SEL undertaking originates from scientific research on emotional intelligence (EI; Salovey \& Mayer, 1990), According to Mayer, Roberts, \& Barsade (2008) these abilities are likely to be associated with social competence, adaptation and academic success.

\subsection{Theories that underpin SEL}

The notion of SEL is founded on the positive youth development which advocates the needs of youth to be addressed by building backgrounds or settings that encourage outcomes like school achievement, mutually sympathetic relationships with adults and peers, problem solving, and civic engagement (Catalano et al., 2004; Greenberg et al., 2003). Attempts to support positive youth development are different from those talored towards lessening risk factors because they are tailored towards cultivating skills, building assets, and promoting flexibility to attaining positive outcomes (Catalano, Hawkins, Berglund, Pollard, \& Arthur, 2002). These Positive youth development interventions such as SEL programming typically use a skill-building, whole-child technique which is based on maintaining assets and not only on preventing problems. Due to the fact that Schools are mainly locations which serve the educational and developmental needs of youth, they therefore are the persuasive targets for common and universal efforts to promote positive youth development.

Zigler and Bishop-Josef (2006) among other researchers are of the view that, to achieve the overall educational goal, school-based programming needs to meet two standards: (1) enhance the social and emotional assets and learning of students across the curriculum, and (2) improve the quality of the environments in which academic, social, and emotional 
learning occurs. The attempt therefore, for the education of the whole child to be successful will depend on the degree to which learning occurs in caring, supportive, safe, and empowering backgrounds and locations which is deeply ingrained in the ecological systems theory and self-determination theory.

The founder of the Ecological systems theory, Bronfenbrenner in 1979, stipulates that, the upbringings youth inhabit, for instance, school, shape their development characteristics of school backgrounds that are associated to positive youth development include opportunities for empowerment and skill building. Catalano and colleagues in 2004 also are of the opinion that the existence of supportive adults and peers help in shaping up students thus leading to their safety and orderliness.

The Self Determination theory postulates that, youth are more likely to flourish when in environments that address their social and emotional needs like experiencing meaningful relationships, having confidence in their abilities, and feeling independent (Deci \& Ryan, 1985). Students are more likely to thrive in classrooms that foster meaningful, caring, safe and empowering interactions (Battistich, Solomon, Watson, \& Schaps, 1997).

\subsection{Scope of SEL}

Emotional Intelligence has been defined as the mental abilities associated with processing and responding to emotions, including recognizing the expression of emotions in others, using emotions to enhance thinking, and regulating emotions to drive effective behaviours (Mayer \& Salovey, 1997; Salovey \& Mayer, 1990). The Collaborative for Academic, Social and Emotional Learning (CASEL), a non-profit entity that advocates and provides leadership for high quality SEL programming and learning standards, classifies five core competencies related to SEL. They are as follows classified; self-awareness, social awareness, self management, relationship skills and responsible decision making.

\section{Methodology}

\subsection{Research design}

A survey design was employed in the study. According to (Cohen, 1988), for a minimum difference to be detected among the sampled population in a survey research, the researcher needs a minimum sample of 64 respondents in each group and to obtain a statistical power of 0.80 at 0.05 level of significance 64 respondents will be necessary in each group. One hundred and thirty (130) respondents were employed in the study. Eighty (80) senior high school students from 8 schools from the Kumasi Metropolis in the Ashanti Region, and fifty (50) students from five (5) schools in the Accra Metropolis in the Greater Accra region of Ghana.

\subsection{Sampling technique}

The convenient sampling method was used in selecting the schools and simple random technique was used in selecting respondents for the study. The study consisted of one hundred and thirty (130) senior high school students from senior high levels one to three (SHS 1-3). Ten (10) students were selected from thirteen schools, eight (8) from Kumasi metro schools which are Opoku Ware senior high, Kwame Nkrumah university senior high (KNUST SHS), Ghana Academy senior high, Kumasi senior high, Prempeh College, Asanteman senior high, Kumasi senior high technical and Kumasi Wesley Girls senior high. The other schools which were selected from the Greater Accra region were Labone senior High, St. Thomas Acquianas senior high, Teshie Presbyterian senior high, Nungua Presbyterian Commercial and senior 
South American Journal of Academic Research

Volume 3, Issue 1, 2016

high school and Nungua senior high school. Selection was based on volutary participation hence the use of convenient and simple random selection tectniques.

Table 1. Demographics of the sample

\begin{tabular}{rlcl}
\hline VARIABLE & NO. & PERCENTAGE \\
\hline Sex & Male & 82 & $63.1 \%$ \\
$\bullet \quad$ Female & 42 & $36.9 \%$
\end{tabular}

Age

- 15

- 16

- 17

- 18

- 19

- 20

- 21

Schools

- Kumasi

- Accra

\section{Level}

- SHS1

- SHS 2

- SHS 3
13

25

47

26

13

5

1

80

50

14

49

67
$10 \%$

$19.2 \%$

$36.2 \%$

$20 \%$

$10 \%$

$3.8 \%$

$0.8 \%$

$61.6 \%$

$38.4 \%$

$10.8 \%$

$37.7 \%$

$51.5 \%$

Total Responses 130

\section{Presentation of results}

Table 2. Summary of independent $t$ test results, means and standard deviations for Self-Awareness, Social Awareness, Relationship Management and Responsible Decision Making categorized by Region of School

\begin{tabular}{llcccccc}
\hline & $\begin{array}{l}\text { Region of } \\
\text { School }\end{array}$ & $\mathbf{N}$ & Mean & $\begin{array}{c}\text { Std. } \\
\text { Deviation }\end{array}$ & $\boldsymbol{t}$ & $\boldsymbol{d} \boldsymbol{f}$ & $\boldsymbol{p}$ \\
\hline Self-Awareness & Greater Accra & 50 & 10.98 & 4.15 & 1.630 & 128 & .105 \\
& Ashanti & 80 & 9.90 & 3.35 & & & \\
\hline Social & Greater Accra & 50 & 18.06 & 7.05 & 1.625 & 128 & .107 \\
Awareness & Ashanti & 80 & 16.18 & 6.02 & & & \\
\hline Self- & Greater Accra & 50 & 12.56 & 4.31 & .145 & 128 & .885 \\
Management & Ashanti & 80 & 12.70 & 5.92 & & & \\
\hline Responsible & Greater Accra & 50 & 10.42 & 3.93 & 2.276 & 128 & .024 \\
$\begin{array}{l}\text { Decision- } \\
\text { Making }\end{array}$ & Ashanti & 80 & 8.80 & 3.96 & & & \\
\hline
\end{tabular}


Results of the independent $\mathrm{t}$ test indicated that there is a significant difference in Responsible Decision-Making among students in schools in the Greater Accra Region and those in the Ashanti Region $[t(128)=2.276, p=.024]$. At the .05 level of significance, Students in schools in the Greater Accra Region $(M=10.42, S D=3.93)$ engaged more in responsible decision-making than their counterparts in the Ashanti Region $(M=8.80, S D=$ 3.96). The results however showed no significant difference in Self-Awareness $[t(128)=$ 1.630, $p=.105]$, Social Awareness [t(128) $=1.625, p=.107]$ and Self-Management $[t(128)=$ $.145, p=.885]$ among students in schools in both the Greater Accra and Ashanti Regions.

Table 3. Summary of independent $t$ test results, means and standard deviations for Self-Awareness, Social Awareness, Self-Management and Responsible Decision Making categorized by Gender

\begin{tabular}{llcccccc}
\hline & Gender & N & Mean & $\begin{array}{c}\text { Std. } \\
\text { Deviation }\end{array}$ & $\boldsymbol{t}$ & $\boldsymbol{d} \boldsymbol{f}$ & $\boldsymbol{p}$ \\
\hline Self-Awareness & Female & 48 & 11.77 & 4.70 & 3.588 & 128 & .000 \\
& Male & 82 & 9.46 & 2.64 & & & \\
\hline Social Awareness & Female & 48 & 19.98 & 7.21 & 4.438 & 128 & .000 \\
& Male & 82 & 15.10 & 5.27 & & & \\
\hline Self- Management & Female & 48 & 14.02 & 5.75 & 2.280 & 128 & .024 \\
& Male & 82 & 11.84 & 4.95 & & & \\
\hline Responsible & Female & 48 & 10.98 & 4.78 & 3.531 & 128 & .001 \\
Decision-Making & Male & 82 & 8.51 & 3.18 & & & \\
\hline
\end{tabular}

An independent $t$ test performed to examine gender differences among the study variables revealed a significant difference among all four variables in terms of gender; Self-Awareness $[t(128)=3.588, p=.000]$, Social Awareness $[t(128)=4.438, p=.000]$, Self- Management $[t(128)=2.280, p=.024]$ and Responsible Decision-making $[t(128)=3.531, p=.001]$. A look at the means revealed Females $(M=11.77, S D=4.70)$ were generally more self-aware than Males $(M=9.46, S D=2.64)$. Also, Females $(M=19.98, S D=7.21)$ scored higher on Social Awareness than Males $(M=15.10, S D=5.27)$. Again, Females $(M=14.02, S D=5.75)$ scored higher on Self- Management than their Male counterparts $(M=11.84, S D=4.95)$. Lastly, Females $(M=10.98, S D=4.78)$ scored higher on Responsible Decision-making than Males $(M=8.51, S D=3.18)$.

Table 4. Pearson r test among the variables of the study

\begin{tabular}{llccccc}
\hline & & $\mathbf{1}$ & $\mathbf{2}$ & $\mathbf{3}$ & $\mathbf{4}$ & $\mathbf{5}$ \\
\hline $\mathbf{1 .}$ & Age & - & & & & \\
2. & Self-Awareness & .159 & - & & & \\
3. & Social Awareness & -.101 & $.442^{* *}$ & - & & \\
4. & Self- Management & -.080 & .154 & $.418^{* *}$ & - & - \\
5. & Responsible & .144 & $.520^{* *}$ & $.435^{* *}$ & .149 &
\end{tabular}

The Pearson's $r$ test revealed a significant positive relationship between Self-awareness and Social awareness $(r=.442, p<.01)$. A significant positive relationship was also found between Social Awareness and Self- Management $(r=.418, p<.01)$. Self-awareness and Selfmanagement were also found to be significantly related positively $(r=.520, p<.01)$. Finally, Social Awareness and Responsible decision-making were also found to be significantly related positively $(r=.435, p<.01)$. All other relationships were not statistically significant. 
South American Journal of Academic Research

Volume 3, Issue 1, 2016

Table 5. Summary of means and standard deviations for Self-Awareness, Social Awareness, SelfManagement and Responsible Decision Making based on Level of study

\begin{tabular}{llccc}
\hline & & N & Mean & Std. Deviation \\
\hline Self-Awareness & SHS 1 & 14 & 7.79 & 2.01 \\
& SHS 2 & 49 & 10.59 & 3.89 \\
& SHS 3 & 67 & 10.64 & 3.66 \\
& Total & 130 & 10.32 & 3.70 \\
\hline Social Awareness & SHS 1 & 14 & 12.93 & 5.51 \\
& SHS 2 & 49 & 17.43 & 6.13 \\
& SHS 3 & 67 & 17.34 & 6.70 \\
& Total & 130 & 16.90 & 6.48 \\
\hline Self- Management & SHS 1 & 14 & 10.79 & 4.89 \\
& SHS 2 & 49 & 13.35 & 5.49 \\
& SHS 3 & 67 & 12.52 & 5.30 \\
& Total & 130 & 12.65 & 5.35 \\
\hline Responsible & SHS 1 & 14 & 8.21 & 3.62 \\
Decision Making & SHS 2 & 49 & 9.82 & 4.16 \\
& SHS 3 & 67 & 9.39 & 3.98 \\
& Total & 130 & 9.42 & 4.01 \\
\hline
\end{tabular}

Table 6. Summary of one-way ANOVA results for Self-Awareness, Social Awareness, SelfManagement and Responsible Decision Making based on Level of study

\begin{tabular}{|c|c|c|c|c|c|c|}
\hline & & $\begin{array}{l}\text { Sum of } \\
\text { Squares }\end{array}$ & $d f$ & $\begin{array}{l}\text { Mean } \\
\text { Square }\end{array}$ & $F$ & Sig. \\
\hline \multirow[t]{3}{*}{$\begin{array}{l}\text { Self- } \\
\text { Awareness }\end{array}$} & $\begin{array}{l}\text { Between } \\
\text { Groups }\end{array}$ & 100.47 & 2 & 50.236 & 3.835 & .024 \\
\hline & Within Groups & 1663.60 & 127 & 13.099 & & \\
\hline & Total & 1764.07 & 129 & & & \\
\hline \multirow{3}{*}{$\begin{array}{l}\text { Social } \\
\text { Awareness }\end{array}$} & $\begin{array}{l}\text { Between } \\
\text { Groups }\end{array}$ & 247.67 & 2 & 123.833 & 3.047 & .051 \\
\hline & Within Groups & 5162.03 & 127 & 40.646 & & \\
\hline & Total & 5409.70 & 129 & & & \\
\hline \multirow{3}{*}{$\begin{array}{l}\text { Self- } \\
\text { Management }\end{array}$} & $\begin{array}{l}\text { Between } \\
\text { Groups }\end{array}$ & 73.55 & 2 & 36.774 & 1.293 & .278 \\
\hline & Within Groups & 3612.18 & 127 & 28.442 & & \\
\hline & Total & 3685.72 & 129 & & & \\
\hline \multirow{3}{*}{$\begin{array}{l}\text { Responsible } \\
\text { Decision } \\
\text { Making }\end{array}$} & $\begin{array}{l}\text { Between } \\
\text { Groups }\end{array}$ & 28.12 & 2 & 14.058 & .872 & .421 \\
\hline & Within Groups & 2047.62 & 127 & 16.123 & & \\
\hline & Total & 2075.73 & 129 & & & \\
\hline
\end{tabular}


levels (i.e. SHS 1 , SHS 2 and SHS 3) $[F(2,127)=3.835, p=.024]$. There was however no significant difference in Social Awareness $[F(2,127)=3.047, p=.051]$, Self- Management $[F(2,127)=1.293, p=.024]$ and Responsible Decision making $[F(2,127)=.872, p=.421]$ among the three study levels.

A Post-hoc analysis using the Bonferroni test was conducted to find out the exact differences that existed in self-awareness among the three levels.

Table 4. Summary of Post Hoc analysis for Self-Awareness based on Level of study

\begin{tabular}{lllccc}
$\begin{array}{l}\text { Dependent } \\
\text { Variable }\end{array}$ & (I) Level & (J) Level & $\begin{array}{c}\text { Mean Difference } \\
\text { (I-J) }\end{array}$ & Std. Error & Sig. \\
\hline $\begin{array}{l}\text { Self- } \\
\text { Awareness }\end{array}$ & SHS 1 & SHS 2 & $2.81^{*}$ & 1.10 & .035 \\
& & SHS 3 & $2.86^{*}$ & 1.06 & .025 \\
& SHS 2 & SHS 1 & $2.81^{*}$ & 1.10 & .035 \\
& & SHS 3 & .05 & .68 & 1.000 \\
& SHS 3 & SHS 1 & $2.86^{*}$ & 1.06 & .025 \\
& & SHS 2 & .05 & .68 & 1.000 \\
\hline
\end{tabular}

*. The mean difference is significant at the 0.05 level.

Multiple comparisons using the Bonferroni test indicated that the mean Self-awareness score for SHS $2(M=10.59, S D=3.89)$ was significantly higher than that for SHS $1(M=7.79$, $S D=2.01)$ but not SHS $3(M=10.64, S D=3.66)$. The mean self-awareness score for SHS 3 was also significantly higher than that for SHS 1.

\section{Discussion}

Current findings indicate that there is a significant difference in Responsible DecisionMaking among students in schools in the Greater Accra Region and those in the Ashanti Region. Students in schools in the Greater Accra Region engaged more in responsible decision-making than their counterparts in the Ashanti Region. Greater Accra region is the capital city of the country, therefore more urban than Ashanti region. There is the possibility that there are more resources in the urban areas and thus schools in the urban areas which include Greater Accra may be enjoying such resources and facilities. Again, most of educators for instance teachers and school counselors who help in building students up prefer to live in the capital city than in other regions. This could also be a factor contributing to students in Greater Accra scoring higher on Responsible decision making. The results on the other hand, showed no significant difference in Self-Awareness, Social Awareness and SelfManagement among students in schools in both the Greater Accra and Ashanti Regions.

Furthermore, results indicated that there was a significant difference among all four variables in terms of gender. Females scored higher than their male counterparts thus were generally more self-aware of themselves, than their male counterparts. Also, females scored higher on Social Awareness than Males. Again, Females scored higher on Self- Management than their Male counterparts. Lastly, Females scored higher on Responsible Decision-making than Males. Longitudinal data suggests that these differences can be somehow explained by behavioral and developmental transformations between boys and girls (Golden, Katz, \& Kuziemko, 2006). Moreso, results indicate that there was a significant difference in Self Awareness among the three study levels (i.e. SHS 1, SHS 2 and SHS 3). Students in SHS 2 scored higher on Self-awareness than SHS 3 students. SHS 3 students also scored higher than SHS1 students. One possible reason for the self-awareness score of SHS 2 students being higher than SHS 3students could be that, SHS 3 students were concentrating on their studies towards their final exams at the time the data was collected for the study. Also, SHS 1 students had just reported to their various schools and barely settling down at the time data was collected. 
South American Journal of Academic Research

Volume 3, Issue 1, 2016

The current study differs in emphasis from previous research by focusing exclusively on social-emotional learning competencies of students in senior high schools. SEL is based on five fundamental competencies which are self-awareness, self -management, social awareness, relationship skills and responsible decision making. The current study was limited to four of the competencies which are self-awareness, self -management, social awareness and responsible decision making. These four competencies are based on students own competencies. Relationship management was not included in the study because the researcher wanted to know if students were aware of their own emotions. It is when students are aware of and understand themselves and their emotions that they better understand others. Future or additional research is required on comparing Relationship management (interpersonal skills) and the other SEL competencies; self-awareness, social awareness, self- management and responsible decision making (intrapersonal skills).

\section{Conclusion}

There is a significant gap between what students' learn in the classroom and what they acquire in their real or future world. Students' Social and Emotional Learning (SEL) which is also known as "total child education" is refered to as the way in which individuals become socially and emotionally intelligent. Usually, it is the process through which children enhance their ability to integrate thinking, feeling, and behaving to achieve important life tasks. Summary of results of the one-way ANOVA indicate that there was a significant difference in Self Awareness among the three study levels (ie. SHS 1, SHS 2 and SHS 3). There was therefore the need to perform multiple comparisons using Bonferroni test. Results indicated that the mean Self-awareness score for SHS 2 was significantly higher than that for SHS 1 but not for SHS 3. The mean self-awareness score for SHS 3 was also significantly higher than that for SHS 1. There was nonetheless no significant difference in Social Awareness, SelfManagement and Responsible Decision making among the three study levels. Again, results indicated that, female students scored higher on all attributes than their male counterparts.

\section{Acknowledgement}

I acknowledge Mawusi Kofi Glozah for helping in analyzing the data collected for this research.

\section{References}

[1] Anamuah-Mensah, J. and Towse, P. Bringing industry into the science classroom- problems, concerns and prospects associated with a paradigm shift, In van Trommel, J. (ed.), Science and technology education in a demanding society(Proceedings of the 7th IOSTE Symposium), Enschede (Netherlands): National Institute for Curriculum Development, Part 4, pp. 165-180, (1995).

[2] Bar-On, J. Maree, G. and Elias M.J. (Eds.), Educating people to be emotionally intelligent (pp. 1-14). Westport, CT: Praeger. (2007).

[3] Barbey, A.K., Colom, R, and Grafman, J. Distributed neural system for emotional Intelligence revealed by lesion mapping. (2012).

[4] Battistich, V. Solomon, D. Watson, M. and Schaps, E. Caring school communities. Educational Psychologist, 32,137-151. doi: 10.1207/s15326985ep3203_1, (1997).

[5] Bronfenbrenner, U. The ecology of human development: Experiments by nature and design. Cambridge, MA:Harvard University Press, (1979).

[6] Caprara, G.V. Barbaranelli, C.P. Bandura, A. and Zimbardo, P.G. Prosocial foundations of children's academic achievement. Psychological Science, 11, 302-306.(2000).

[7] Catalano, R. F. Hawkins, J. D. Berglund, L. Pollard, J. A. and Arthur, M. W. Prevention science and positive youth development: Competitive or cooperative frameworks? Journal of Adolescent Health, 31, 230-239. doi:10.1016/S1054-139X(02)00496-2, (2002).

[8] Catalano, R. F. Berglund, L. Ryan, J. A. M. Lonczek, H. S. and Hawkins, J. D. Positive youth development in the United States: Research findings on evaluations of positive youth development programs. The Annals of the American Academy of Political and Social Science, 591, 98-124. doi: 10.1177/0002716203260102, (2004).

[9] Collaborative for Academic Social and Emotional Learning, Safe and sound: An educational leader's guide to evidence-based social and emotional learning (SEL) programs, (2003).

[10]. Cohen, J. Statistical power analysis for the behavioral sciences (2nd ed.). Hillsdale, NJ: Lawrence Erlbaum. 1988.

[11] Deci, E. L. and Ryan, R. M. Intrinsic motivation and self-determination in human behavior. New York: Plenum, (1985).

[12] Dugah, S.C. JHS students to resit BECE-recipe for mediocrity? www.myjoyonline.com. Nov 25 (2013) 


\section{South American Journal of Academic Research}

Volume 3, Issue 1, 2016

[13] Gardner. H. Multiple intelligences: The theory in practice. New York: Basic Books. (1993)

[14] Elias, M. J. Zins, J. E. Weissberg, R. P. Frey, K. S. Greenberg M.T. and Haynes, N. M. Promoting social and emotional learning: Guidelines for educators. Alexandria, VA: Association for Supervision and Curriculum Development.(1997).

[15] Elias, M. J. Prepare children for the tests of life, not a life of tests. Education Week, 21(4), 40. (2001).

[16] Engelmann, S. and Carnine, D. Theory of instruction: Principles and applications (Rev. Ed.). Eugene, OR: ADI Press. (1991).

[17] Golden, C. Katz, L. F. and Kuziemko, I. The homecoming of American college women: The reversal of the college gender gap. Journal of Economic Perspectives, 20, 133-156. (2006)

[18] Goleman, D. Emotional intelligence. New York: Bantam Books, (1995).

[19] Greenberg, M. T. Weissberg, R. P. O'Brien, M. U. Zins, J. E. Fredericks, L. Resnik, H. and, Elias, M. J. Enhancing school-based prevention and youth development through coordinated social, emotional, and academic learning. American Psychologist, 58, 466-474. doi: 10.1037/0003-066X.58.6-7.466, (2003).

[20] Heckman, J. and Masterov, D. V. The productivity argument for investing in young children: Committee on Economic Development, Working Paper \#5, ( 2004).

[21] Huitt, W. Moral and character development. Educational Psychology Interactive. Valdosta, GA: Valdosta State University. (2004).

[22] Lieberman, M.D. Social cognitive neuroscience: A review of core processes. Annual Review of Psychology, 58:25, 9-89. (2007).

[23] Malecki, C.K. and Elliott, S.N. Children's social behaviors as predictors of academic achievement: A longitudinal analysis. School Psychology Quarterly, 17, 1 - 23, (2002).

[24]. Mayer, J. D. Roberts, R. D. and Barsade, S. G. Human abilities: Emotional intelligence. Annual Review of Psychology, 59, 507-536. doi: 10.1146/annurev.psych.59.103006.093646, 2008. ISSN 2394-9686. (2008).

[25] Mayer, J. D. and Salovey, P. What is emotional intelligence? In P. Salovey \& D. J. Sluyter (Eds.), Emotional development and emotional intelligence: Educational implications (pp. 3-34). New York, NY: Basic Books, Inc.,(1997).

[26] Mayer, J. D. A field guide to emotional intelligence. In J. Ciarrochi, J. P. Forgas, \& J. D. Mayer (Eds.), Emotional intelligence in everyday life (pp. 3-24). Philadelphia: Taylor \& Francis. (2001).

[27] Muskin, J.A. Becoming an independent entrepreneur in the formal sector of northern Cote d'Ivoire: what role can primary schooling play? International Journal of Educational Development, 17: 265 - 283. (1997).

[28] Noah., H. J. and Eckstein, M. A. Doing Comparative Education: Three Decades of Collaboration. Hong Kong: University of Hong Kong Comparative Education Research Center.351 pp. (1998).

[29] Salovey P. and Mayer, J. D. Emotional intelligence. Imagination, Cognition and Personality, 9, 185-211. doi:10.2190/DUGG-P24E-52WK-6CDG, (1990).

[30] Stenberg, R.J. Beyond IQ: A Triarchic theory of human Intelligence New York. Cambridge University Press. 1985.

[31] Stevenson, R. The Huddersfield experiment, Chemistry in Britain, 31(11): 845 -847, (1995).

[32] Shriver, T. P. and Weissberg, R. P. No emotion left behind. New York Times OP-ED, A15. (2005).

[33] Tabron, G. and Yang, J. The interaction between technical and vocational education and training (TVET) and economic development in advanced countries, International Journal of Educational Development, 17: 323 - 334, (1997).

[34] Tengey, J.Y. and Ganu, M. K. Building Students Overall Success on Students' Emotional Learning. International Journal of Novel Research in Education and Learning, Vol. 2, Issue 3, pp: 54-59. (2015).

[35] Tengey, J.Y. Students' Emotional Learning and the Act of Public Speaking: Role of School Counselors in Building Students' Confidence. International Journal of Science and Research Publications, Vol. 5, Issue 9. (2015).

[36] Towse, P.J. An evaluation of the Lesotho Introductory Science Improvement Programmer, with particular reference to the effects of this course on attitudes to and an understanding of, science, M.Ed. thesis, University of Hull. (1977).

[37] Zigler, E. F. and Bishop-Josef, S. J. The cognitive child vs. the whole child: Lessons from 40 years of Head Start. (2006)

[38] Zins, J. Payton, J. Weissberg, R. and O’Brien, M. Social and emotional learning for successful school performance. In Matthews G., Zeidner M. and Roberts R. The science of emotional intelligence: Knowns and unknowns New York: Oxford University press. (2007). 